\title{
Assessment of watermelon accessions for salt tolerance using stress tolerance indices
}

\author{
Avaliação de acessos de melancia para tolerância ao sal utilizando \\ índices de tolerância ao estresse
}

\author{
Ercan Ekbic ${ }^{1 \star}$, Cagri Cagıran¹, Kursat Korkmaz², Malik Arsal Kose¹, Veysel Aras ${ }^{3}$ \\ 'University of Ordu, Department of Horticulture, Faculty of Agriculture, Ordu, Turkey \\ 2University of Ordu, Department of Soil Science and Plant Nutrition, Faculty of Agriculture, Ordu, Turkey \\ ${ }^{3}$ Alata Horticultural Research Institute, Mersin, Turkey \\ *Corresponding author: ercanekbic@gmail.com \\ Received in May 12, 2017 and approved in September 29, 2017
}

\begin{abstract}
Salt stress is the most significant constraint for agricultural production in arid and semi-arid regions. Thus, genetically improved stresstolerant varieties are needed for the future. The identification of salt-tolerant genotypes is the starting point for such breeding studies. This study was conducted to determine and assess the tolerance of different watermelon genotypes under saline conditions. Twenty-two watermelon genotypes and accessions were grown in pots with $3 \mathrm{~kg}$ of soil in four saline stress conditions $\left(0 \mathrm{mmol} \mathrm{kg}{ }^{-1}\right.$ as the control, 25 , 50 and $100 \mathrm{mmol} \mathrm{kg}^{-1} \mathrm{NaCl}$ ). The detrimental effects of salt stress on the plants were evident with increasing doses of $\mathrm{NaCl}$. Stress indices calculated over the plant dry weights under the $100 \mathrm{mmol} \mathrm{kg}^{-1}$ salinity level were used to assess the salt tolerance of the genotypes. Stress intensity was calculated as 0.76 . Such a value indicated that the highest dose of salt exerted severe stress on the plants. The G04, G14 and G21 genotypes were considered to be salt tolerant, since these genotypes showed the highest values of K/Na and Ca/ $\mathrm{Na}$ ratios in the plant tissue. The losses in dry mass at severe salt stress reached $75.48 \%$. In principal component analyses, the genotypes had positive correlations with stress tolerance indices of MP (mean productivity), GMP (geometric mean productivity) and STI (stress tolerance index). The GMP and STI indices indicated that G04 (a member of Citrullus colocynthis), G14 and G21 could be prominent sources to develop salt tolerance.
\end{abstract}

Index terms: Citrullus lanatus; local varieties; stress tolerance attributes; tolerance for salt stress.

\begin{abstract}
RESUMO
O estresse salino é a restrição mais importante para a produção agrícola em regiões áridas e semi-áridas. Portanto, há necessidade de plantas geneticamente tolerantes ao estresse salino no futuro. Identificação de genótipos tolerantes ao sal é o ponto de partida de estudos de melhoramento. O presente estudo foi conduzido para determinar e avaliar a tolerância de diferentes genótipos de melancia sob condições salinas. Um total de 22 genótipos e acessos de melancia foram cultivados em vasos de 3 kg de solo com quatro condições de estresse salino diferentes ( $0 \mathrm{mmol} \mathrm{kg}^{-1}$ como controle, 25,50 e $100 \mathrm{mmol} \mathrm{kg}^{-1} \mathrm{de} \mathrm{NaCl}$ ). Dependendo do aumento da dose de $\mathrm{NaCl}$, os efeitos prejudiciais do estresse salino nas plantas também aumentaram. Os índices de estresse calculados sobre os pesos secos das plantas com um nível de salinidade de $100 \mathrm{mmol} \mathrm{kg}^{-1}$ foram utilizados para avaliar a tolerância ao sal dos genótipos. A intensidade de tensão foi calculada como 0.76. Indicando que a maior dose de sal exerce um estresse salino grave nas plantas. Os genótipos G04, G14 e G21 foram considerados tolerantes, uma vez que apresentaram os maiores valores nas relações $\mathrm{K} / \mathrm{Na}$ e $\mathrm{Ca} / \mathrm{Na}$. As perdas em pesos secos com estresse salino grave atingiram $75.48 \%$. Na análise de componentes principais, os genótipos tiveram correlações positivas com os índices de tolerância ao estresse de PM (produtividade média), GMP (produtividade média geométrica) e STI (índice de tolerância ao estresse). Os índices GMP e STI indicaram G04 (um membro de C. colocynthis), G14 e G21 como materiais proeminentes para a tolerância ao sal.
\end{abstract}

Termos para indexação: Citrullus lanatus; variedades locais; atributos de tolerância ao estresse; tolerância ao estresse salino.

\section{INTRODUCTION}

Intensive input use, especially excessive fertilizer use, ultimately results in polluted lands. Salinity is a common problem in agricultural lands in arid and semi-arid regions. It negatively influences plant water potential and ion balance; has toxic impacts on plants, destroys plant metabolism, ultimately results in drastic yield losses; and exerts significant threats on the agricultural production of countries (Munns; Termaat, 1986; Sharma; Rao; Saxena, 2004; Wang et al., 2014). The majority of the plants cannot survive under high soil salinity conditions, or they exhibit weak development and growth, resulting in serious yield and quality losses. A decrease in the number of leaves and leaf sizes, short plant heights and reduced dry weights are among the primary salt hazards. In addition, saline 
conditions disrupt the physiological and metabolic activities of plants as a result of osmotic stress (Slama et al., 2015). Osmotic imbalance in salt stress conditions results in water deficit, stomatal closure and excess $\mathrm{Na}^{+}$ ion accumulation in older leaves (Roy; Negrao; Tester, 2014).

Increasing agricultural productions by solving salt stress problems in agricultural lands is a significant issue to meet the food demands of an ever-increasing world population. Improved irrigation techniques or soil reclamation practices provide expensive and palliative solutions for salinity problems (Singh; Singh, 2000). Nevertheless, some chemical applications such as jasmonic acid decrease the detrimental effects of salt stress (Azooz; Ashraf; Abou-Elhamd, 2015). Genetic variations in the salt tolerance of several plants have been defined, and such variations have been successfully used in cultural practices. Defining a salt tolerant genitor in watermelon gene sources may provide significant germ plasm sources for upcoming breeding studies. Plant resistance to salt stress is managed by several genes (Silva; Geros, 2009), but it is also influenced considerably by environmental conditions. Therefore, the identification of salt-tolerant genotypes is the starting point of breeding studies.

Various stress indices were developed and used for the selection of stress-tolerant genotypes by measuring plant performance under stress and taking normal conditions into account (Fischer; Maurer, 1978; Rosielle and Hamblin, 1981; Fernandez, 1992; Mitra, 2001; Porch, 2006; Singh et al., 2015; Krishnamurthy et al., 2016). With these indices, performance losses under stress conditions compared to normal conditions are identified, and the severity of stress is determined. These indices are usually based on the resistance or sensitivity of genotypes to stress conditions (Fernadez, 1992). Rosielle and Hamblin (1981) defined the difference in plant performance under normal conditions (Yp) and stress conditions (Ys) as stress tolerance (TOL) and defined the average performance under both conditions as the mean productivity (MP).

However, if there is a large difference between the Yp and Ys, then the MP may allow the selection of sensitive genotypes. Such a case then negatively influences the success of selection. Instead, the geometric mean productivity (GMP), which is less sensitive to extreme values, is more successful to select superior genotypes under both stress and normal conditions than the MP index. Another study indicated that the stress sensitivity index (SSI) was not independent from the productivity potential of the genotype and indicated the potential of the genotypes (Fischer; Maurer, 1978). Fernandez (1992) defined the stress tolerance index (STI) and indicated that the STI might be effective in the selection of high-yield genotypes under both stress and normal conditions. Stress indices have not been used to select salt stress-tolerant watermelon genotypes. The present study was conducted to determine the effects of salinity on plant growth characteristics and to assess the efficiency of stress indices in the identification of salt stress-tolerant watermelon genotypes based on their dry mass under high saline stress conditions.

\section{MATERIAL AND METHODS}

Watermelon genotypes and cultivars were obtained from the watermelon genetic resources of the Alata Horticulture Research Station. A total of 22 watermelon genotypes were utilized in this study: 18 local watermelon genotypes collected from different regions of Turkey, three commercial cultivars (G01, G02, G03) and one Citrullus colocynthis accession (G04: tolerant to salt stress). Experiments were conducted in an unheated greenhouse with $28^{\circ} \mathrm{C}$ day and $18^{\circ} \mathrm{C}$ night temperatures. Watermelon seeds were sown in peat-filled vials. When the seedlings had 2-3 true leaves, they were transplanted into $3 \mathrm{~kg}$ pots filled with sand-clay soil (pH: 6.6, EC: $\left.0.11 \mathrm{dS} \mathrm{m}^{-1}\right)$.

The experiment was conducted using completely randomized plots in an experimental design of three replications. Following the transplantation of the seedlings, $300 \mathrm{mg} \mathrm{kg}^{-1} \mathrm{~N}\left(\mathrm{NH}_{4} \mathrm{SO}_{4}\right), 100 \mathrm{mg} \mathrm{kg}^{-1} \mathrm{P}$ $\left(\mathrm{KH}_{2} \mathrm{PO}_{4}\right)$ and $125 \mathrm{mg} \mathrm{kg}^{-1} \mathrm{~K}\left(\mathrm{KH}_{2} \mathrm{PO}_{4}\right)$ fertilizers (as solution) were applied to the pots for normal plant growth. Sodium chlorite $(\mathrm{NaCl})$ (Merck) was used to create salt stress conditions. Genotypes were tested under a control plot $\left(0 \mathrm{mmol} \mathrm{kg}^{-1} \mathrm{NaCl}\right)$ and three different $\mathrm{NaCl}$ treatments $\left(25 \mathrm{mmol} \mathrm{kg}^{-1}, 50 \mathrm{mmol} \mathrm{kg}{ }^{-1}\right.$ and $\left.100 \mathrm{mmol} \mathrm{kg}{ }^{-1}\right)$ to represent different stress conditions. Data obtained from the different salt stress (mild-to-severe) conditions were used to assess the effects of $\mathrm{NaCl}$ on the plants' growth habit and nutritional content for all genotypes. Additionally, stress indices were calculated using the data obtained from control plots (as the normal environment) and $100 \mathrm{mmol} \mathrm{kg}^{-1} \mathrm{NaCl}$ applied plots (as the severe salt stress environment). The salt treatments were initiated five days after transplanting, and $25 \mathrm{mmol} \mathrm{kg}^{-1}$ was applied in the first treatment. The highest salt treatment $\left(100 \mathrm{mmol} \mathrm{kg}^{-1}\right)$ was added in three applications with 
2-day intervals to avoid acute impacts. The plants were left to grow for four weeks after they had been treated with the salt. All of the standard horticultural practices were implemented regularly and fully. At the end of the $4^{\text {th }}$ week, the plants were harvested by cutting them from the soil surface. The harvested plants were washed with tap water and roughly dried with paper towels. The main shoot length and fresh mass were measured. Plants were then dried in paper bags at $70{ }^{\circ} \mathrm{C}$ for $48 \mathrm{~h}$ and reweighed to obtain their dry mass. Measurement of $\mathrm{Na}, \mathrm{K}, \mathrm{Ca}, \mathrm{Mg}$, $\mathrm{P}, \mathrm{Fe}, \mathrm{Zn}, \mathrm{Cu}$ and $\mathrm{Mn}$ were performed by an inductively coupled plasma optical emission spectrometer (ICP-OES; Vista-Pro Axial; Agilent Tech., Mulgrave, Australia) after digesting the leaf samples ( $0.2 \mathrm{~g}$ of each sample) in a closed microwave digestion system (MarsExpress CEM Corp., Matthews, NC) in the presence of concentrated $\mathrm{HNO}_{3}(5 \mathrm{ml})$ and $\mathrm{H}_{2} \mathrm{O}_{2}(2 \mathrm{ml})$. Deionized water was used to bring the volume of the samples to $20 \mathrm{ml}$. The analytical data was compared with the certified values of a standard reference material (SRM 1573a Tomato Leaf, National Institute of Standards and Technology, Gaithersburg, MD).

Stress tolerance indices were calculated over the dry mass of control and the plants subjected to $100 \mathrm{mmol} \mathrm{kg}^{-1}$ salinity level by using the following equations:

Stress intensity (SI) $1-\left(\frac{Y \bar{s}}{Y \bar{p}}\right)$ (Fischer; Maurer, 1978);

Tolerance $(\mathrm{TOL})=\left(Y_{p}-Y_{s}\right)($ Rosielle; Hamblin, 1981); Mean Productivity $(\mathrm{MP})=\left(Y_{s}-Y_{p}\right) / 2$ (Rosielle; Hamblin, 1981);

Geometric Mean Productivity $($ GMP $)=\sqrt{Y_{\mathrm{s}} \times Y_{p}}$ (Fernandez, 1992);

Stress Sensitivity Index $(\mathrm{SSI})=\left(1-\left(Y_{s} / Y_{p}\right)\right) / S I$ (Fischer; Maurer, 1978);

Stress Tolerance Index $(\mathrm{STI})=\left(Y_{s} \times Y_{p}\right) /\left(Y_{\bar{p}}\right)^{2}$ (Fernandez, 1992);

where $Y p$ : Performance under normal conditions; $Y_{s}$ : Performance under stress conditions; $Y \bar{p}$ : Mean performance of the genotypes under normal conditions; $Y \bar{s}$ : Mean performance of the genotypes under stress conditions.

Descriptive statistics for the nutrients and plant growing characteristics were analyzed with SPSS v.12 statistical software. Principal component analysis (PCA) was performed with Jump v.10.0 statistical software, and the biplot of the first two principal components was drawn.

\section{RESULTS AND DISCUSSION}

\section{Effect of salt stress on some plant growing parameters}

Descriptive statistics of the main shoot lengths and of the fresh and dry mass $(\mathrm{g})$ of the different salt treatments and the control are shown in Table 1. The values decreased with increasing salt stress levels. While the decreases in the main shoot lengths and fresh weights were similar to each other, there were severe decreases in the plant dry weights. Compared to the control treatment, there was a $61.44 \%$ decrease in the main shoot length, a $60.75 \%$ decrease in fresh weight and a $75.48 \%$ decrease in dry weight under high salt stress conditions. Research conducted on pepper (Chartzoulakis; Klapaki, 2000), watermelon and gourd species (Yetisir; Uygur, 2009), eggplant (HaiJun et al., 2013), tomato (Kiran et al., 2014; Tuna, 2014) and cucumber (Tavares de Albuquerque et al., 2016) all reported that saline conditions dramatically limited the plant growing parameters such as plant height, fresh weight and dry weight.

\section{Effect of salt stress on plant nutrient contents of watermelon genotypes}

Descriptive statistics for the plant nutrients of local watermelon genotypes are shown in Table 2. The data showed that a minor decrease was observed in $\mathrm{P}$ contents with increasing salt stress levels. Because the dry mass of the watermelon genotypes was reduced, the $\mathrm{Na}, \mathrm{Ca}, \mathrm{Mg}, \mathrm{Zn}$ and $\mathrm{Cu}$ contents in plant tissue increased along with the saline stress level. Alternatively, the K, $\mathrm{Fe}$ and $\mathrm{Mn}$ contents of the genotypes exhibited different responses to saline conditions. While increasing $\mathrm{K}$ and $\mathrm{Mn}$ contents were observed under low salinity stress levels, these values decreased under high salinity levels. High concentrations of sodium can inhibit the uptake of $\mathrm{K}$ by plants through the antagonism between these two ions as well as potassium ion leakage when Ca substitutes for $\mathrm{Na}$ in the cell membranes (Marschner, 1995). Uygur and Yetisir (2006) investigated the phosphorus uptake of different squash genotypes under saline conditions. These researchers reported that severe $\left(16 \mathrm{dS} \mathrm{m}^{-1}\right)$ salt stress resulted in 3-fold increases in leaf $\mathrm{P}$ contents of sensitive squash genotypes and such increases then resulted in P toxicity in these sensitive genotypes. Alternatively, Oliveira Bosco et al. (2009) reported that progressive salt stress levels increased the $\mathrm{Na}$ and $\mathrm{Cl}$ ions in the leaves of eggplant and resulted in reductions in the $\mathrm{Ca}$, $\mathrm{Mg}$ and $\mathrm{K}$ levels. 
Table 1: Descriptive statistics of watermelon genepool based on some morphological traits in different saline conditions.

\begin{tabular}{|c|c|c|c|c|c|c|c|}
\hline $\begin{array}{c}\mathrm{NaCl} \\
\left(\mathrm{mmol} \mathrm{kg}^{-1}\right)\end{array}$ & & $\begin{array}{l}\text { Shoot length } \\
(\mathrm{cm})\end{array}$ & $\begin{array}{l}\text { Fresh mass } \\
\left(\mathrm{g} \mathrm{plant}^{-1}\right)\end{array}$ & $\begin{array}{l}\text { Dry mass } \\
\left(\text { ( } \text { plant }^{-1}\right)\end{array}$ & RMSL (\%) & RMFW (\%) & RMDW (\%) \\
\hline \multirow{4}{*}{$\begin{array}{l}\text { Control } \\
(0)\end{array}$} & Min. & 52.33 & 34.53 & 5.66 & \multirow{4}{*}{ - } & \multirow{4}{*}{-} & \multirow{4}{*}{-} \\
\hline & Max. & 127.00 & 56.39 & 11.21 & & & \\
\hline & Mean & 75.08 & 45.73 & 8.40 & & & \\
\hline & Std. Dev. & 15.18 & 4.75 & 1.26 & & & \\
\hline \multirow{4}{*}{25} & Min. & 47.67 & 26.10 & 3.58 & \multirow{4}{*}{-18.85} & \multirow{4}{*}{-21.39} & \multirow{4}{*}{-33.45} \\
\hline & Max. & 110.67 & 47.58 & 7.28 & & & \\
\hline & Mean & 60.93 & 35.95 & 5.59 & & & \\
\hline & Std. Dev. & 14.01 & 4.68 & 0.82 & & & \\
\hline \multirow{4}{*}{50} & Min. & 27.33 & 20.13 & 2.25 & \multirow{4}{*}{-48.28} & \multirow{4}{*}{-47.04} & \multirow{4}{*}{-64.17} \\
\hline & Max. & 81.00 & 28.55 & 3.78 & & & \\
\hline & Mean & 38.83 & 24.22 & 3.01 & & & \\
\hline & Std. Dev. & 10.72 & 2.17 & 0.48 & & & \\
\hline \multirow{4}{*}{100} & Min. & 20.67 & 10.66 & 0.76 & \multirow{4}{*}{-61.44} & \multirow{4}{*}{-60.75} & \multirow{4}{*}{-75.48} \\
\hline & Max. & 55.00 & 22.35 & 2.59 & & & \\
\hline & Mean & 28.95 & 17.95 & 2.06 & & & \\
\hline & Std. Dev. & 7.02 & 2.85 & 0.46 & & & \\
\hline
\end{tabular}

RMSL= Reduction in mean shoot length; RMFW= Reduction in mean fresh weight; RMDW= Reduction in mean dry weight; Min= Minimum; Max= Maximum; Std. Dev= Standard deviation.

Table 2: Descriptive statistics of the watermelon gene pool based on the mineral elements under saline conditions.

\begin{tabular}{|c|c|c|c|c|c|c|c|c|c|c|}
\hline \multicolumn{2}{|c|}{$\mathrm{NaCl}\left(\mathrm{mmol} \mathrm{kg}^{-1}\right)$} & $\begin{array}{l}\mathrm{Na} \\
(\%)\end{array}$ & $\begin{array}{c}\mathrm{K} \\
(\%)\end{array}$ & $\begin{array}{l}\mathrm{Ca} \\
(\%)\end{array}$ & $\begin{array}{l}\mathrm{Mg} \\
(\%)\end{array}$ & $\begin{array}{c}P \\
(\%)\end{array}$ & $\begin{array}{c}\mathrm{Fe} \\
\left(\mathrm{mg} \mathrm{kg}^{-1}\right)\end{array}$ & $\begin{array}{c}\mathrm{Zn} \\
\left(\mathrm{mg} \mathrm{kg}^{-1}\right)\end{array}$ & $\begin{array}{c}\mathrm{Cu} \\
\left(\mathrm{mg} \mathrm{kg}^{-1}\right)\end{array}$ & $\begin{array}{c}\mathrm{Mn} \\
\left(\mathrm{mg} \mathrm{kg}^{-1}\right)\end{array}$ \\
\hline \multirow{4}{*}{$\begin{array}{c}\text { Control } \\
(0)\end{array}$} & Min. & 0.29 & 1.11 & 3.36 & 0.39 & 0.18 & 109.56 & 82.95 & 3.91 & 29.82 \\
\hline & Max. & 0.37 & 2.08 & 4.89 & 0.55 & 0.35 & 277.24 & 119.33 & 50.08 & 61.54 \\
\hline & Mean & 0.32 & 1.72 & 4.25 & 0.45 & 0.27 & 189.97 & 91.75 & 11.45 & 39.60 \\
\hline & Std. Dev. & 0.02 & 0.26 & 0.43 & 0.04 & 0.05 & 40.32 & 7.45 & 10.99 & 7.62 \\
\hline \multirow{4}{*}{25} & Min. & 0.37 & 1.47 & 3.84 & 0.43 & 0.19 & 106.54 & 85.70 & 11.14 & 36.25 \\
\hline & Max. & 0.67 & 3.25 & 6.58 & 0.68 & 0.33 & 355.21 & 118.15 & 23.70 & 79.35 \\
\hline & Mean & 0.52 & 2.37 & 5.25 & 0.54 & 0.27 & 175.44 & 104.39 & 15.92 & 60.42 \\
\hline & Std. Dev. & 0.08 & 0.38 & 0.67 & 0.08 & 0.03 & 51.23 & 7.79 & 4.04 & 10.30 \\
\hline \multirow{4}{*}{50} & Min. & 0.61 & 2.18 & 4.15 & 0.45 & 0.17 & 39.04 & 94.30 & 10.82 & 37.34 \\
\hline & Max. & 1.00 & 3.79 & 7.06 & 0.68 & 0.32 & 251.91 & 124.54 & 26.61 & 85.08 \\
\hline & Mean & 0.74 & 2.83 & 5.38 & 0.59 & 0.23 & 100.31 & 107.52 & 17.69 & 55.40 \\
\hline & Std. Dev. & 0.10 & 0.42 & 0.69 & 0.06 & 0.04 & 52.66 & 6.75 & 4.42 & 11.96 \\
\hline \multirow{4}{*}{100} & Min. & 1.66 & 1.68 & 4.72 & 0.54 & 0.16 & 72.34 & 93.79 & 12.78 & 39.75 \\
\hline & Max. & 3.48 & 3.55 & 7.36 & 0.78 & 0.27 & 268.02 & 139.94 & 45.34 & 58.68 \\
\hline & Mean & 2.29 & 2.60 & 6.28 & 0.66 & 0.22 & 160.02 & 112.09 & 22.01 & 50.23 \\
\hline & Std. Dev. & 0.47 & 0.46 & 0.81 & 0.07 & 0.03 & 41.00 & 12.34 & 8.00 & 4.99 \\
\hline
\end{tabular}

Min= Minimum; Max= Maximum; Std. Dev= Standard deviation. 
In studies of the salt stress tolerance of plants, the potassium-to-sodium ratio $(\mathrm{K} / \mathrm{Na})$ and the calciumto-sodium ratio $(\mathrm{Ca} / \mathrm{Na})$ are used as tolerance criteria in which higher ratios indicate a lower rate of inhibition from Na-induced stress (Salehi; Arzani, 2014). Compared to the control treatment, the $\mathrm{K} / \mathrm{Na}$ and $\mathrm{Ca} / \mathrm{Na}$ ratios significantly decreased under high salt stress levels (Table 3 ). While the mean $\mathrm{K} / \mathrm{Na}$ ratio of the local genotypes was 5.46 , and the $\mathrm{Ca} / \mathrm{Na}$ ratio was 13.52 under normal conditions, the values decreased to 1.19 and 2.87, respectively, under high salt stress conditions. An analysis of the $\mathrm{K} / \mathrm{Na}$ ratios of the genotypes under high salt stress levels indicated that the greatest values were obtained from the G04, G14 and G21 genotypes, and the lowest values were obtained from the G01, G09, G19 and G20 genotypes. Similar results were obtained with the $\mathrm{Ca} / \mathrm{Na}$ ratios. While the greatest values were observed in the G04, G14, G21 and G22 genotypes, the lowest values were observed in the G01, G11, G19 and G20 genotypes. Thus, the genotypes of G04, G14 and G21 with the greatest $\mathrm{K} / \mathrm{Na}$ and $\mathrm{Ca} / \mathrm{Na}$ ratios were considered to be salt stress-tolerant genotypes. ShiNong and ShiRong (2009) indicated that watermelon plants grafted on squash rootstocks take up a greater concentration of $\mathrm{K}^{+}$ions from the soil rather than taking up $\mathrm{Na}^{+}$under salt stress conditions. Yasar, Uzal and Yasar (2013) carried out a study examining the salt stress-tolerance of watermelon genotypes and indicated that the plants selectively took up $\mathrm{Na}^{+}$and $\mathrm{K}^{+}$ion under salt stress conditions, and the resistant genotypes promoted the uptake of $\mathrm{K}^{+}$ions rather than $\mathrm{Na}^{+}$ions. Moreover, under salinity stress conditions, with increasing salt concentration, the $\mathrm{K}^{+}$ion concentration increases in salt tolerant plants (Goreta et al., 2008; Yetisir; Uygur, 2009). Therefore, the $\mathrm{K} / \mathrm{Na}$ ratio represents the tolerance level of a genotype. Yang, Newton and Miller (1990) reported that $\mathrm{K} / \mathrm{Na}$ ratios increased in salt tolerant plants. In addition, Dasgan et al. (2002) reported that the $\mathrm{K} / \mathrm{Na}$ ratio could be used reliably in the selection of plants tolerant to salt stress.

\section{Stress indices and correlations}

Breeders usually start by screening genetic pools to identify resistant or tolerant genotypes under stress conditions. Different criteria are employed other than the $\mathrm{K} / \mathrm{Na}$ ratio in the identification of stresstolerant individuals. Stress tolerance indices have long been used in screening studies to identify drought or stress tolerant genotypes in beans (Porch, 2006), cowpeas (Fernandez, 1992), wheat (Fisher; Maurer, 1978; Asadi et al., 2012) and paddy (Hosseini et al., 2012; Krishnamurthy et al., 2016).
Table 3: $\mathrm{K} / \mathrm{Na}$ and $\mathrm{Ca} / \mathrm{Na}$ mean ratios of genotypes under normal and severe salt stress conditions.

\begin{tabular}{ccccc}
\hline \multirow{2}{*}{ Genotypes } & \multicolumn{2}{c}{ Control $(0 \mathrm{mM})$} & \multicolumn{2}{c}{$100 \mathrm{mM}$} \\
\cline { 2 - 5 } & $\mathrm{K} / \mathrm{Na}$ & $\mathrm{Ca} / \mathrm{Na}$ & $\mathrm{K} / \mathrm{Na}$ & $\mathrm{Ca} / \mathrm{Na}$ \\
\hline G01 & 5.59 & 12.77 & 0.78 & 1.62 \\
G02 & 5.24 & 15.63 & 1.28 & 3.33 \\
G03 & 6.08 & 14.05 & 0.95 & 2.14 \\
G04 & 5.88 & 12.19 & 1.94 & 3.96 \\
G05 & 5.78 & 14.49 & 1.40 & 2.83 \\
G06 & 5.96 & 11.72 & 1.05 & 2.15 \\
G07 & 5.87 & 11.99 & 1.38 & 3.76 \\
G08 & 5.33 & 14.11 & 1.04 & 3.09 \\
G09 & 6.36 & 16.31 & 0.65 & 2.62 \\
G10 & 6.13 & 14.71 & 1.37 & 3.40 \\
G11 & 4.24 & 12.58 & 1.09 & 1.97 \\
G12 & 4.28 & 13.96 & 1.20 & 2.29 \\
G13 & 5.17 & 12.35 & 1.38 & 3.24 \\
G14 & 6.83 & 14.33 & 1.66 & 3.85 \\
G15 & 6.29 & 13.79 & 1.06 & 2.35 \\
G16 & 5.81 & 11.71 & 1.56 & 3.59 \\
G17 & 4.94 & 13.49 & 1.12 & 2.85 \\
G18 & 4.27 & 16.04 & 0.95 & 2.69 \\
G19 & 4.82 & 11.77 & 0.66 & 2.06 \\
G20 & 5.29 & 13.08 & 0.71 & 1.67 \\
G21 & 6.58 & 15.85 & 1.72 & 3.91 \\
G22 & 3.44 & 10.42 & 1.16 & 3.84 \\
\hline Means & 5.46 & 13.52 & 1.19 & 2.87 \\
\hline Std. Dev. & 0.86 & 1.61 & 0.35 & 0.77 \\
\hline
\end{tabular}

Std. Dev= Standard deviation.

The stress intensity calculated over the dry mass of 22 watermelon genotypes and cultivars under high salt stress levels was identified as 0.76 (Table 4). Such a value indicated highly significant stress levels in watermelons. The stress index values of the genotypes are shown in Table 4 . The dry matter quantities of the watermelon genotypes produced under salt stress conditions varied between $0.76 \mathrm{~g}$ and $2.59 \mathrm{~g}$, and the values under normal conditions varied between $5.66 \mathrm{~g}$ and $10.25 \mathrm{~g}$. While the G22, G10 and G12 genotypes yielded the greatest dry weights under stress conditions, the lowest value was observed in the G03 genotype. While the genotypes G14, G04 and G21 had the greatest dry weights under normal 
conditions, the lowest values were observed in the G09 and G18 genotypes. The greatest values of mean productivity (MP), calculated as the mean performance under normal and stress conditions, were observed in the G04, G14 and G21 genotypes and the lowest in the G09, G11 and G18 genotypes. Measurements of the geometric mean productivity (GMP) indicated that the greatest values were observed in the G04, G14, G21 and G22 genotypes, and the lowest values were observed in the G03, G11, G15 and G17 genotypes.
Alternatively, the greatest tolerance index (TOL) values were observed in the G03, G04, G14 and G21 genotypes and the lowest in the G05, G09 and G18 genotypes. With regard to the stress sensitivity index (SSI), the greatest values were seen in the G03, G11 and G15 genotypes, and the lowest values were observed in the G09 and G18 genotypes. Considering the stress tolerance index (STI) of the genotypes, it was observed that the genotypes G04 (0.34), G14 (0.33), G22 (0.32) and G21 (0.31) had higher values.

Table 4: Estimates of salt tolerance attributes from dry mass data for watermelon genotypes.

\begin{tabular}{|c|c|c|c|c|c|c|c|}
\hline Genotypes & $Y_{p}$ & $\mathrm{Y}_{\mathrm{S}}$ & $\mathrm{MP}$ & $\mathrm{TOL}$ & GMP & $\mathrm{SSI}$ & STI \\
\hline G01 & 8.21 & 1.74 & 4.97 & 6.48 & 3.77 & 1.04 & 0.20 \\
\hline G02 & 8.54 & 1.99 & 5.26 & 6.56 & 4.12 & 1.02 & 0.24 \\
\hline G03 & 8.81 & 0.76 & 4.78 & 8.06 & 2.58 & 1.21 & 0.09 \\
\hline G04 & 11.11 & 2.18 & 6.64 & 8.93 & 4.91 & 1.06 & 0.34 \\
\hline G05 & 7.44 & 2.39 & 4.92 & 5.05 & 4.22 & 0.90 & 0.25 \\
\hline G06 & 8.76 & 2.15 & 5.46 & 6.61 & 4.34 & 1.00 & 0.27 \\
\hline G07 & 8.75 & 2.09 & 5.42 & 6.67 & 4.27 & 1.01 & 0.26 \\
\hline G08 & 7.65 & 2.30 & 4.98 & 5.35 & 4.20 & 0.92 & 0.25 \\
\hline G09 & 5.66 & 2.40 & 4.03 & 3.26 & 3.69 & 0.76 & 0.19 \\
\hline G10 & 7.79 & 2.55 & 5.17 & 5.24 & 4.45 & 0.89 & 0.28 \\
\hline G11 & 7.48 & 1.30 & 4.39 & 6.18 & 3.12 & 1.09 & 0.14 \\
\hline G12 & 8.34 & 2.45 & 5.39 & 5.89 & 4.52 & 0.93 & 0.29 \\
\hline G13 & 8.44 & 2.36 & 5.40 & 6.08 & 4.46 & 0.95 & 0.28 \\
\hline G14 & 11.21 & 2.06 & 6.63 & 9.15 & 4.80 & 1.08 & 0.33 \\
\hline G15 & 7.98 & 1.37 & 4.67 & 6.61 & 3.30 & 1.10 & 0.15 \\
\hline G16 & 8.68 & 2.21 & 5.44 & 6.47 & 4.38 & 0.99 & 0.27 \\
\hline G17 & 7.87 & 1.42 & 4.64 & 6.45 & 3.34 & 1.08 & 0.16 \\
\hline G18 & 6.64 & 2.39 & 4.51 & 4.26 & 3.98 & 0.85 & 0.22 \\
\hline G19 & 8.75 & 2.17 & 5.46 & 6.58 & 4.35 & 1.00 & 0.27 \\
\hline G20 & 7.88 & 2.20 & 5.04 & 5.68 & 4.16 & 0.95 & 0.24 \\
\hline $\mathrm{G} 21$ & 10.18 & 2.16 & 6.17 & 8.02 & 4.69 & 1.04 & 0.31 \\
\hline $\mathrm{G} 22$ & 8.72 & 2.59 & 5.65 & 6.13 & 4.75 & 0.93 & 0.32 \\
\hline Mean & 8.40 & 2.06 & 5.23 & 6.35 & 4.11 & 0.99 & 0.24 \\
\hline Std. Dev. & 1.26 & 0.46 & 0.66 & 1.37 & 0.59 & 0.10 & 0.03 \\
\hline SI & 0.76 & & & & & & \\
\hline
\end{tabular}

$Y_{p}=$ Dry weight under normal condition; $Y_{S}=$ Dry weight under saline condition; MP = Mean dry weight; GMP = Geometric mean dry weight; TOL= Tolerance; SSI = Stress susceptibility index; STI = Stress tolerance index; Std. Dev= Standard deviation; SI = Stress intensity. 
Correlation coefficients between the stress indices of watermelon genotypes grown under salt stress conditions are shown in Table 5. The performance of genotypes under normal conditions (Yp) was highly correlated with the MP (0.94) and GMP (0.94). The GMP index was also highly correlated with the Ys (0.83). Alternatively, the Ys correlated negatively with the TOL $(-0.40)$ and SSI $(-0.83)$. Such negative correlations indicated that the genotypes with high TOL and SSI values had low values under stress conditions. There was a high positive correlation between the TOL and SSI (0.82). The STI had significant positive correlations with the Ys (0.80), MP (0.80) and GMP (0.99). The correlations between the dry weights under normal conditions and the dry weights under stress conditions were found to not be significant. Such insignificant correlations indicated that the genotypes with high performances under normal conditions did not yield similar responses under stress conditions, and thus the tolerance levels of the genotypes were different from each other.

Table 5: Linear correlation among stress index attributes.

\begin{tabular}{ccccccc}
\hline & $Y p$ & $Y s$ & $M P$ & GMP & TOL & SSI \\
\hline Ys & $-0.06^{\text {ns }}$ & 1.00 & & & & \\
MP & $0.94^{* *}$ & $0.29^{\text {ns }}$ & 1.00 & & & \\
GMP & $0.49 *$ & $0.83^{* *}$ & $0.76^{* *}$ & 1.00 & & \\
TOL & $0.94^{* *}$ & $-0.40^{\text {ns }}$ & $0.76^{* *}$ & $0.17^{\text {ns }}$ & 1.00 & \\
SSI & $0.58^{* *}$ & $-0.83^{* *}$ & $0.27^{\text {ns }}$ & $-0.38^{\text {ns }}$ & $0.82^{* *}$ & 1.00 \\
STI & $0.55^{*}$ & $0.80 * *$ & $0.80^{* *}$ & $0.99 * *$ & $0.23^{\text {ns }}$ & $-0.33^{\text {ns }}$ \\
\hline
\end{tabular}

YP = Dry weight under normal condition; YS = Dry weight under saline condition; MP = Mean dry weight; GMP = Geometric mean dry weight; TOL= Tolerance; $\mathrm{SSI}=$ Stress susceptibility index; STI = Stress tolerance index; Ns= not significant; $*=$ significant at $5 \%$ level; $* *=$ significant at $1 \%$ level.

Asadi et al. (2012) reported that the GMP and STI indices were quite distinctive in the identification of the salttolerance of bread wheat. Hosseini, Sarvestani and Pirdashti (2012) indicated the paddy genotypes with high MP and STI index values and low SSI values to be salt-tolerant. In another study, Krishnamurthy et al. (2016) indicated that the GMP and STI indices identified the salt-tolerant genotypes, and the TOL and SSI indices were able to separate sensitive paddy genotypes. In addition, in beans, the STI and GMP indices were found to effectively identify drought-tolerant genotypes (Porch, 2006). Similarly, in some other studies, positive correlations of salt-tolerance with the MP, GMP and STI indices were reported (Clarke et al., 1984; Winter; Musick; Porter 1988; Mardeh et al., 2006).

\section{Principal Component Analysis (PCA) and Biplot Display}

Statistical multivariate algorithms are highly effective methods to characterize genetic materials and elucidate the genetic relations among them (Mohammadi; Prasanna, 2003).

The relationships between the genotypes and stress tolerance indices are shown in Table 6 and Figure 1. A biplot display is usually carried out with principal component analysis allowing visual assessments of the relationships between the genotypes and stress indices by placing each index over different axes. While the first principal component had a high positive correlation with the MP (0.98), STI (0.91), GMP (0.88) and Yp (0.85) indices, it explained $55.6 \%$ of the total variation. The second principal component had a high positive correlation with the SSI (0.99) and TOL (0.78) and a negative correlation with the Ys (-0.88), GMP (-0.47) and STI (-0.42) indices and explained $43.9 \%$ of the total variation. These two principal components together explained $99.5 \%$ of the total variation among watermelon genotypes. The first principle component constituted $3.89 \%$ of the variation in salt-tolerance indices, and the second principal component constituted $3.07 \%$ of such variations. The genotypes G04, G14 and G21 ranked strongly in the STI, GMP and MP indices. Alternatively, the sensitive genotype G03 ranked strongly in the SSI index. The TOL index did not separate the genotypes significantly based on stress conditions.

Table 6: Principal component for salt stress indices based on dry mass of watermelon genotypes.

\begin{tabular}{ccc}
\hline Traits & Dimension1 & Dimension 2 \\
\hline Yp & 0.85 & 0.53 \\
Ys & 0.47 & -0.88 \\
MP & 0.98 & 0.19 \\
TOL & 0.62 & 0.78 \\
GMP & 0.88 & -0.47 \\
SSI & 0.09 & 0.99 \\
STI & 0.91 & -0.42 \\
Eigen value & 3.89 & 3.07 \\
Percentage of variation & 55.59 & 43.92 \\
Cumulative percentage & 55.59 & 99.51 \\
Chi-Square & 967.04 & 885.82 \\
Prob>Chi-Square & $<.0001$ & $<.0001$ \\
\hline
\end{tabular}




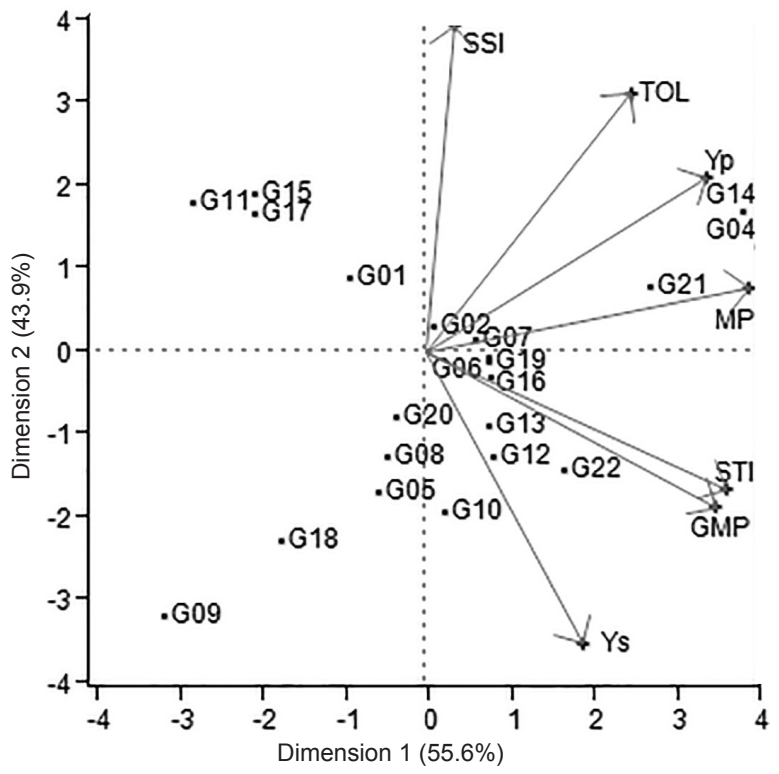

Figure 1: The biplot display of stress-tolerance attributes and watermelon genotypes based on dry mass levels under salt stress conditions $(\mathrm{SI}=0.76)$.

Singh et al. (2015) carried out a study on the salt tolerance of bread wheat and indicated that principle component analysis separated the genotypes into two groups. These researchers reported that the first two principal components were able to explain $99.74 \%$ of the variation among the genotypes, the first principal component constituted $5.24 \%$ of variation in the salt tolerance indices, and the second component constituted $3.74 \%$.

Collado et al. (2015) reported that the GMP, MP and STI indices clearly identified and grouped the high yielding maize accessions in both the stress and normal environments by biplot. Moreover, it was reported that principal component analysis showed that the shoot dry weight had the highest contribution and was associated with the GMP, MP and STI indices in stress environments. Krishnamurthy et al. (2016) reported that the first dimension of biplot analysis explained $66.9 \%$ of the total variation among paddy genotypes under salt stress conditions. These researchers also reported high correlations of seed yields with the MP, GMP and STI indices and negative correlations with the TOL and SSI indices. The second dimension of the biplot explained $32.1 \%$ of the total variation, and seed yields were positively correlated with the TOL and SSI indices (Krishnamurthy et al. 2016). Fernandez (1992) carried out a study with cowpea genotypes and reported that the first dimension of the biplot explained $63 \%$ of the total variation among genotypes under severe stress conditions and that there were high correlations among the MP, SSI and STI. The second dimension of the biplot explained $39 \%$ of the total variation, and there was a positive correlation between the TOL and Yp (Fernandez, 1992).

\section{CONCLUSIONS}

To our knowledge, this is the first study on the responses of watermelon genotypes to salt stress. This study found that stress indices could yield reliable selections for watermelon genotypes under high salt stress conditions. Watermelon genotypes are generally sensitive to high salt stress conditions and, as expected, the dry weights of the genotypes decreased under stress conditions. The stress indices calculated over the dry weights were highly successful at identifying salt-tolerant genotypes and delineated the genetic variability among watermelon genotypes in terms of their salt tolerance levels. Of the stress indices used in this study, the GMP and STI indicated that the G04, G14 and G21 were tolerant genotypes. Thus, these stress indices were highly effective at screening the watermelon genotypes for salt stress.

\section{ACKNOWLEDGMENTS}

The authors thank the Research Project Coordinator of Ordu University (TF-1331) for financial support of this research.

\section{REFERENCES}

ASADI, M. et al. Assesment of salinity tolerance of different promising lines of bread wheat (Triticum aestivum L.). Advances in Applied Science Research, 3(2):1117-1121, 2012.

AZOOZ, M. M.; ASHRAF, M.; ABOU-ELHAMD, M. F. Jasmonateinduced tolerance of Hassawi okra seedlings to salinity in brackish water. Acta Physiologiae Plantarum, 37:77, 2015.

CHARTZOULAKIS, K.; KLAPAKI, G. Response of two greenhouse pepper hybrids to $\mathrm{NaCl}$ salinity during different growth stages. Scientia Horticulturae, 86:247260, 2000.

CLARKE, J. M. et al. Growth analysis of spring wheat cultivars of varying drought resistance. Crop Science, 24(3):537541, 1984. 
COLLADO, M. B. et al. Evaluation of salinity tolerance indices in seedling of maize (Zea mays L.). Revista de la Facultad de Agronomía, La Plata, 114(1):27-37, 2015.

DASGAN, H. Y. et al. Determination of screening techniques to salinity tolerance in tomatoes and investigation of genotype responses. Plant Science, 163:695-703, 2002.

FERNANDEZ, G. C. J. Effective selection criteria for assessing stress tolerance. In: KUO, C. G. (Ed.). Proceedings of the International Symposium on Adaptation of Vegetables and Other Food Crops in Temperature and Water Stress, Tainan, Taiwan, 1992. p.257-270.

FISCHER, R. A.; MAURER, R. Drought resistance in spring wheat cultivars. I. Grain yield response. Australian Journal of Agricultural Research, 29:897-907, 1978.

GORETA, S. et al. Vegetative growth, superoxide dismutase activity and ion concentration of salt-stressed watermelon as influenced by rootstock. The Journal of Agricultural Science, 146(6):695-704, 2008.

HAl-JUN, Z. et al. Growth, ion distribution and salt-tolerance mechanism of eggplant seedlings under salt stress. Journal of China Agricultural University, 18(4):77-83, 2013.

HOSSEINI, S. J.; SARVESTANI, Z. T.; PIRDASHTI, H. Analysis of tolerance indices in some rice (Oryza sativa L.) genotypes at salt stress condition. International Research Journal of Applied and Basic Sciences, 3(1):1-10, 2012.

KIRAN, S. et al. Changes on some characteristics of tomato genotypes in different tolerance levels for salt stress under drought stress conditions. Journal of Agricultural Faculty of Gaziosmanpasa University, 31(3):41-48, 2014.

KRISHNAMURTHY, S. L. et al. Effect of different salt stresses on agro-morphological traits and utilisation of salt stress indices for reproductive stage salt tolerance in rice. Field Crops Research, 190:26-33, 2016.

MARSCHNER, H. Mineral nutrition of higher plants. 2. Ed. London: Academic Press, 1995. 889p.

MARDEH, A. et al. Evaluation of drought resistance indices under various environmental conditions. Field Crops Research, 98:222-229, 2006.

MITRA, J. Genetics and genetic improvement of drought resistance in crop plants. Current Science, 80:758-762, 2001.

MOHAMMADI, S. A.; PRASANNA, B. M. Analysis of genetic diversity in crop plants - Salient statistical tools and considerations. Crop Science, 43(4):1235-1248, 2003.
MUNNS, R.; TERMAAT, A. Whole-plant responses to salinity. Australian Journal of Plant Physiology, 13(1):143-160, 1986.

OLIVEIRA BOSCO, M. R. de et al. Influence of salt stress on the mineral composition of eggplant seedlings. Revista Ciência Agronômica, 40(2):157-164, 2009.

PORCH, T. G. Application of stress indices for heat tolerance screening of common bean. Journal of Agronomy and Crop Science, 192:390-394, 2006.

ROSIELLE, A. A.; HAMBLIN, J. Theoretical aspects of selection for yield in stress and non-stress environments. Crop Science, 21:943-946. 1981

ROY, S. J.; NEGRAO, S.; TESTER, M. Salt resistant crop plants. Current Opinion in Biotechnology, 26:115124, 2014.

SALEHI, M.; ARZANI, A. Evaluation of triticale genotypes for salt tolerance using physiological traits. Emirates Journal of Food and Agriculture, 26(3):277-283, 2014.

SHARMA, R. C.; RAO, B. R. M.; SAXENA, R. K. Salt affected soils in India - Current assessment. In: Advances in sodic land reclamation. International Conference on Sustainable Management of Sodic Lands, 9-14 February, Lucknow, India, p.1-26. 2004.

SHINONG, Z.; SHIRONG, G. Effects of grafting on $\mathrm{K}+, \mathrm{Na}+$ contents and distribution of watermelon (Citrullus vulgaris Schrad.) seedlings under $\mathrm{NaCl}$ stress. Acta Horticulturae Sinica, 36(6):814-820, 2009.

SILVA, P.; GEROS, H. Regulation by salt of vacuolar $\mathrm{H+-}$ ATPase and $\mathrm{H}+$-pyrophosphatase activities and $\mathrm{Na}+/$ $\mathrm{H}+$ exchange. Plant Signaling and Behavior, 4(8):718726, 2009.

SINGH, S. et al. Assessment of multiple tolerance indices for salinity stress in bread wheat (Triticum aestivum L.). Journal of Agricultural Science, 7(3):49-57, 2015.

SINGH, S.; SINGH M. Genotypic basis of response to salinity stress in some crosses of spring wheat Triticum aestivum L. Euphytica, 115:209-214, 2000.

SLAMA, I. et al. Diversity, distribution and roles of osmoprotective compounds accumulated in halophytes under abiotic stress. Annals of Botany, 115(3):1-15, 2015.

TAVARES DE ALBUQUERQUE, J. R. et al. Crescimento inicial e tolerância de cultivares de pepino sob estresse salino. Revista Brasileira de Agricultura Irrigada, 10(2):486495, 2016. 
TUNA, A. L. Influence of foliarly applied different triazole compounds on growth, nutrition, and antioxidant enzyme activities in tomato (Solanum lycopersicum L.) under salt stress. Australian Journal of Crop Science, 8(1):71-79, 2014.

UYGUR V.; YETISIR H. Phosphorous uptake of gourds species and watermelon under different salt stress. Journal of Agronomy, 5(3):466-470, 2006.

WANG, Y. H. et al. Screening okra varieties of salt tolerance and correlation analysis among salt tolerance indices at germinating stage. Southwest China Journal of Agricultural Sciences, 27(2):788-792, 2014.

WINTER, S. R.; MUSICK, J. T.; PORTER, K. B. Evaluation of screening techniques for breeding drought-resistant winter wheat. Crop Phisiology and Metabolism, 28(3):512-516, 1988.

YANG, Y. W.; NEWTON, R. J.; MILLER, F. R. Salinity tolerance in Sorghum. 1. Whole plant response to sodium chloride in $S$. bicolor and S. halepense. Crop Science, 30:775-781, 1990.

YASAR, F.; UZAL, O.; YASAR, O. Identification of ion accumulation and distribution mechanisms in watermelon seedlings (Citrullus lanatus (Thunb.) Mansf.) grown under salt stress. Yüzüncü Yil Üniversitesi Journal of Agricultural Sciences, 23(3):209-214, 2013.

YETISIR, H.; UYGUR, V. Plant growth and mineral element content of different gourd species and watermelon under salinity stress. Turkish Journal of Agriculture and Forestry, 33:65-67, 2009. 